\title{
Reimagining Anger in Christian Traditions: Anger as a Moral Virtue for the Flourishing of the Oppressed in Political Resistance
}

\author{
Wonchul Shin (1) \\ Columbia Theological Seminary, Decatur, GA 30030, USA; shinw@ctsnet.edu
}

Received: 26 April 2020; Accepted: 11 May 2020; Published: 14 May 2020

\begin{abstract}
This paper aims to reimagine anger, which has been traditionally understood as one of the capital vices in Christian traditions, as a moral virtue of the oppressed in their resistance against structural injustice. This essay first examines the contemporary discussions on anger in the field of Christian ethics. Then, I critically evaluate Lisa Tessman's account of "burdened virtues" and argue for a possibility that anger can be constructive in contributing to the flourishing of the oppressed. This paper argues that the oppressed can transform burdened anger into thriving anger that is conducive to their own flourishing through the communal bearing of the burden. This paper provides empirical support for this argument: a comparative analysis of a suicide protest of a college student and life-affirming protest of the mothers and wives of political victims against the totalitarian regime of Park Chung-hee in South Korea, 1970-1979.
\end{abstract}

Keywords: anger; moral virtue; burdened virtue; flourishing; the oppressed; political resistance

\section{Introduction}

Throughout Christian traditions, anger has been understood as one of capital vices that have to be eschewed in Christian life. The Apostle Paul exhorted early Christians to "put away" and "get rid of" anger (Ephesians 4:31; Colossians 3:8) since it has "the potential to tear down the (Christian] community apart instead of building it up" (Powell 2016, p. 357). In his Praktikos, Evagrius of Pontus, one of the Desert Fathers in the fourth century, names anger as one of the eight forms of "dangerous reasoning" (logismoi), which are "not so much the great sins themselves," but "tendencies or negative-thought trajectories" that destroy the healthy soul (Corrigan 2009, pp. 73-75). In the sixth century, St. Gregory the Great modified Evagrius' list and classified anger as one of the seven "deadly sins (or capital sins)." ${ }^{1}$ Following the deadly sins of tradition, many Christians have been taught that "Christians should not feel angry" and reach "sanctification" or "perfection" in the Christian life by eliminating the deadly sin of anger (Lester 1983, pp. 15-16).

On the other hand, in Christian traditions, there have been polyphonic voices on anger to understand it as a virtue. Specifically, some pioneering feminist theologians and ethicists challenged the conventional understanding of anger as a capital vice or a deadly sin and highlighted a virtuous aspect of anger. Rosemary Radford Ruether identifies anger alongside pride with a theological virtue that is "grace welling up from the ground" of the oppressed women to "transcend false consciousness (the internalized psychology of denigration) and break its chains (of sexism)" (Ruether 1973, p. 1226).

1 The tradition of the seven deadly sins was further consolidated and sophisticated by St. Thomas Aquinas in the 13th century. Specifically, he classified "three species" of anger: (1) fel (the irascible temperament), (2) mania (the nursing of injuries), and (3) furor (rancorous anger). It is important to note that the third can be identified as a deadly sin in catholic tradition. See John Deely's article (Deely 1997, pp. 80-82). 
For her, anger is "the work of liberating grace," "the presence of God empowering" the women, who "have been more deeply socialized to repress their anger" in patriarchal society, to liberate themselves from "the patterns of victimization and marginalization" (Ruether 1993, pp. 6-7). ${ }^{2}$ Beverly Wildung Harrison claims anger as a "mode of connectedness to others" and a "vivid form of caring" which informs us that "something is amiss" in our social relations (i.e., lack of human solidarity and rupture of mutual relationship) (Harrison 1981, p. 49). Then, she argues that anger calls for the urgent need of "transformation in relation" and serves as "the rising power" for practicing "the central virtues of the Christian moral life," "radical acts of love" in "expressing human solidarity and bringing mutual relationship to life" (ibid., pp. 49-52).

In the field of Christian ethics (or moral theology), over the past decades, Christian ethicists and moral theologians also have examined this contested topic of anger. The first section of this essay offers an overview of their works published in this field and then argues for its own contribution to discovering a marginalized voice on this topic: while acknowledging the intrinsic tragedy in anger enacted by an oppressed community in the contexts of political oppression and liberatory struggle, at the same time construing anger as a moral virtue for the oppressed community's flourishing.

For this task, in the second section, this paper critically reviews virtue philosopher Lisa Tessman's account of anger as a burdened virtue: anger can be understood as a morally praiseworthy virtue for political resisters in the particular context of political oppression and liberatory struggles, but it imposes burdens on their bearers since it is "disconnected from his/her own flourishing" (Tessman 2005, p. 114). I criticize her account of anger as too pessimistic and argue for the possibility of the constructive role of anger in contributing to the flourishing of the oppressed by highlighting the communal sharing of the burden of anger. In the final section, this paper provides empirical support for this argument-the possibility of transformation of burdened anger into thriving anger-through a comparative analysis of a suicide protest of a Korean college student and life-affirming/flourishing protest of the mothers and wives of political victims against the totalitarian regime of Park Chung-hee in South Korea, 1970-1979.

\section{The Contemporary Discussions on Anger in the Field of Christian Ethics}

In his essay “Do You Do Well to Be Angry?" published in the Annual of the Society of Christian Ethics, William Werpehowski (1996) defends the possibility of the constructive role of anger in the Christian moral life but qualifies this possibility with some conditions. He defines anger as a "painful affection arising from some moral wrong suffered by oneself or others with whom one is connected," accompanied by the desire for "the restoration of moral order" (ibid., pp. 59-60). For him, one can do well to be angry since this affection can be a "fitting response to a moral slight or injustice" (ibid., p. 65). Drawing on Aristotelian virtue theory, however, this fitting (or virtuous) response arising from the affection of anger is possible when the anger is accompanied with what Aristotle calls "the virtue of 'gentleness' (praotes)" that guides the anger to attain the mean between the two vices (ibid., p. 63). Using everyday examples of anger in interpersonal relationships, Werpehowski demonstrates the two extreme poles of anger which are destructive vices in the moral life: (1) the excess of anger, "irascibility" and (2) the deficiency of anger, "submissiveness" or "servility" (ibid., pp. 62-67). A "gentle" person virtuously disposes oneself to be good and angry in both securing one's own "dignity" against "unjust subordination to or merger with another" and restoring "communion" or "human bonds" with wrongdoers beyond mere punishment or vengeance (ibid., pp. 68-70).

Werpehowski then offers a theological argument for naming "pride" - "the self's attention on itself" - as the foundation of the destructive anger, specifically the vice of irascibility that desires "the securities of power" by "erasing the other" in violent ways (ibid., pp. 71-72). However, he still defends the possibility of transformation of this sinful anger grounded in pride into the gentle anger by "charity"

2 The Living Pulpit volume 2 contains other short but seminar articles highlighting the positive aspects of anger in Christian traditions. See John Bennett (1993), Keith A. Russell (1993), and Thomas H. Troeger (1993). 
(ibid., p. 76). For him, charity means to decenter the sinful self from its loyalty to one's own power and reorient oneself toward what Edwards calls as "zeal for the honor of God" and consequently love of neighbor (ibid., p. 75). The transformed, rightly ordered anger by charity "rules out vengeance and ill-will" and serves as "the hope for reconciliation" in the Christian moral life (ibid., p. 76).

However, in her essay "Anger, Justice, and Detachment" published later in the same journal, Diane Yeager challenges theo-philosophical accounts of the "good anger" by pointing out "the corrosive effects of anger" in moral life, specifically the Christian moral life (Yeager 1997, p. 171). While she acknowledges a "great impact" of Harrison's "powerful and appealing argument" of anger as "the signal" and "the source" for social transformation, she argues for the intrinsic theological "flaws" of anger: its sinfulness (ibid., p. 171). From two novels, Diary of a Country Priest by Georges Bernanos and Dombey and Son by Charles Dickens, Yeager critically examines literary examples of "just anger" expressed in the interpersonal relationships between characters and claims that "there is something intrinsically wrong and destructive" even in the just anger (ibid., p. 186). She identifies this intrinsic wrongness and destructiveness with a sin of "the desiring self's attachment to temporal goods" that wedges us away from our gratitude and trust of God (ibid., pp. 185-88). Her theological analysis of anger is similar to Werpehowski's, but she puts more weight on the intrinsic sinfulness of anger than on the possibility of the transformation of the sinful anger by charity.

After carefully reviewing the essays of Werpehowski and Yeager, William Mattison discovers a neglected question in the contemporary discussions of anger in Christian ethics: "What sense does it make for the emotion of anger (or any emotion for that matter) to be called virtuous?" (Mattison 2004, p. 160). In his essay "Virtuous Anger?" published in the Journal of the Society of Christian Ethics, as the title of this essay explicitly asking, Mattison mainly examines whether the emotion of anger itself "regardless of any action issuing from one's anger" could be labeled as a virtue (ibid., p. 160). Following Thomas Aquinas' account of virtuous anger, Mattison argues for the possibility of defining the emotion of anger itself as a praiseworthy virtue. However, as Aquinas notes that "some anger is a virtue and some anger is not," Mattison stipulates the necessary condition of a virtuous anger: it must be "reasonable" in its object and mode (ibid., pp. 167-68). He then suggests three progressive steps for the development of virtuous anger corresponding to Aquinas' three models of reason's governance of passion. ${ }^{3}$ The first step is to "recognize vicious [disordered] anger and stop acting upon it" (ibid., p. 172). The second step is to develop "a good propensity to anger by attempting to shape (usually subdue) the anger itself" through "cognitive manipulation" (ibid., p. 173). The last step requires of continued habituation of the preceding two steps so that one's anger is reasonable and thus virtuous in its "initial arousal" (ibid., p. 174).

Although Mattison's essay contributed to construing anger as a moral virtue, his analytic and normative framework for understanding anger is limited to an individual level or at best interpersonal level. This lack of proper attention to a social dimension of anger, specifically systemic injustice as the structural cause of a community's anger, can be also found in the previous essays of Werpehowski and Yeager. The three ethicists converge on their understanding of anger as a response to injustice experienced in interpersonal relationships. Given this limitation, the anger of a particular community, the oppressed who have suffered under systemic injustice and engaged struggles for their liberation, has been marginalized as a focal subject of discussions. Recently, however, some ethicists have added new voices on the marginalized topic in the field of Christian ethics.

Michael P. Jaycox's essay "The Civic Virtues of Social Anger" challenges the field of Catholic theological ethics on its lack of "a normative framework" for analyzing and evaluating contemporary public expression of "social anger" that arises in "social groups and entire communities" (Jaycox 2016, p. 123). He keenly pays attention to "the social location of the agents who are angry" and

3 Ki Joo Choi's recent article (Choi 2018) on the affections and emotions is helpful to understand the moral difference between the affections and emotions. Virtuous anger that I argue for in this essay aligns with one of the affections rather than emotions, though systematic analysis of virtuous anger as affection will be a different research project. 
"the particular emotion of anger with reference to systemic injustice or public life" (ibid., pp. 126-28). With this attention, he suggests social anger as a kind of intellectual virtue equipping a social group with "a cognitive interruption of the ideological rationalizations for oppression and privilege" or "a transgressive judgment that systemic injustice is stymieing the basic human flourishing of a vulnerable social group" (ibid., pp. 128-29). For him, social anger is also a kind of civic virtue that has to contribute to "a right realization of universal moral ends in public life" (ibid., p. 131). For this public mission, social anger needs to accompany with other civic virtues-"restorative justice, conflictual solidarity, prophetic prudence" - that serves as "normative heuristics" to "evaluate particular instances of social anger" in terms of its appropriateness to promote institutional reforms and human dignity (ibid., p. 131).

While Jaycox primarily reconstructs a normative framework for the virtuous social anger with reference to systemic injustice, Sarah MacDonald and Nicole Symmonds focus on reconstructing a particular moral discourse of an oppressed group's anger, specifically manifested in rioting. In their essay "Rioting as Flourishing?", MacDonald and Symmonds identifies rioting with a "manifestation of anger" of people who "have either directly or indirectly experienced systemic oppression or violence" (MacDonald and Symmonds 2018, p. 31). They defend the possibility of virtuous anger expressed in rioting as "a tactic of political resistance and a deliberate action of moral agency," rather than "destructive or violent civil unrest" (ibid., p. 30). Drawing on Lisa Tessman's concept of burdened virtues, MacDonald and Symmonds affirm the anger of rioters as a morally praiseworthy and even necessary virtue in the context of liberatory struggles, but at the same time acknowledge some burdens that hamper "a flourishing life" (ibid., p. 30). Nevertheless, they attempt to open the possibility of the rioters' flourishing by expanding the notion of flourishing to include their dedicated contribution to eventually "ending the oppressive conditions currently blocking flourishing" at present (ibid., p. 39).

In this essay, I also primarily aim to reconstruct a particular moral discourse of an oppressed group's anger in the contexts of systemic oppression and political resistance. ${ }^{4}$ This essay also mainly draws on Tessman's account of burdened virtues in order to construe the constructive role of anger as a moral virtue for the oppressed. However, this essay points out the intrinsic tragedy in anger enacted by the oppressed in their political resistance: the tragic burden of self-sacrifice that the resisters cannot but bear and which hampers their own flourishing. In the essay "Rioting as Flourishing?" the authors take the rioters during the Arab Spring uprising as an example of burdened virtue-bearers, but there was a more tragically relevant example: Mohamed Bouzazizi, the Tunisian street vendor, who burned himself with the flame of anger as his utmost protest. Bouzazizi's self-immolation throws a challenging question about whether we can still argue for the possibility of the constructive anger in promoting flourishing of the oppressed in their political resistance. In the second section of this essay, I critically examine Tessman's account of burdened virtues in order to respond to this question.

4 Few womanist ethicists reconstructed particular virtue discourses of the marginalized communities (i.e., African American communities). Katie Cannon carefully observes the life of Zora Neale Hurston and highlights the moral values that are central in the Black community to guide their own life and maintain a "feistiness about life" under the structural violence of White supremacy (Cannon 1998, p. 91). She explicitly names "unctuousness" as one of the primary moral virtues of the Black community: "Creatively straining against the external restraints (structural injustices) in one's life is virtuous living" (ibid., p. 92). For Cannon, Hurston concretely embodied this particular virtue throughout her life by celebrating "the value of rich reservoir of materials passed along in the oral tradition of her parents, neighbors, and common everyday people" and confronting "the almost universal understanding" of Black culture and folkways as "inferior, comic, and primitive" (ibid., p. 93). In other words, Cannon uncovers the underrepresented virtue of the Black community cherished in their daily strategies of survival and resistance under/against structural injustices. Following Cannon's method of "mining virtues and values in the work of black literary artists," Melanie L. Harris constructs a "womanist virtue ethic based on values derived from [Alice] Walker's own ethic and virtues gleaned from her nonfiction essays" (Harris 2010, p. 11). Harris presents a list of particular virtues that "are habitually practiced by women of African descent and are worthy of being passed on women living in the present day": (1) generosity, (2) graciousness, (3) compassion, (4) spiritual wisdom, (5), audacious courage, (6) justice, and (7) good community (ibid., pp. 114-23). However, both womanist ethicists do not offer a constructive proposal for reimagining anger in Christian traditions, specifically the tradition of Christian ethics. Anger is not included in their list of particular virtues of the marginalized. 


\section{Critical Review of Lisa Tessman's Account of Burdened Virtues}

In the field of moral philosophy and Christian ethics, there are few existing studies on the theme of particular virtues of an oppressed community under conditions of systemic injustice. ${ }^{5}$ One of these studies is Lisa Tessman's account of virtue ethics for liberatory struggles. In her "Burdened Virtues", she pays keen attention to the issue of structural oppression and lived experiences of the oppressed in their survival and resistance. From the beginning, she clearly states her concern with "the selves who endure and resist [systemic] oppression" (Tessman 2005, p. 3).

She then identifies two forms of moral trouble of the oppressed. First, the oppressed under oppression can be "morally damaged, prevented from developing or exercising certain virtues" (ibid., p. 4). The most devastating effect of systemic oppression would be the internalization of marginalization into the very soul of the self: it also blocks the oppressed from empowering themselves to recognize and address the root cause of oppression.

The second form of moral trouble is very important for this essay. Even if the oppressed overcome the first form of moral trouble by empowering themselves to practice moral virtues, they are still vulnerable to the second form of moral trouble: disconnection from their own flourishing. The oppressed can bear a set of character traits that could be affirmed as moral virtues within the context of political struggle and resistance. However, Tessaman points out that these traits of the oppressed are indeed moral virtues, but somewhat damaged virtues, or what she calls "burdened virtues" that have the unusual features of being "disjoined from their bearer's own flourishing" (ibid., p. 4).

In other words, burdened virtues refer to particular moral virtues of the oppressed embodied in their practices of resistance against systemic oppression. These virtues can be morally praiseworthy since they contribute to empowering the oppressed and sustaining their liberatory struggles: they are recommended and even required within the context of oppression. Nevertheless, these virtues are burdened since they are tragically "unhealthy" in terms of the well-being of the oppressed: while engaging political resistance, these virtues motivate the oppressed to sacrifice their own lives or their own possibilities of flourishing, "the affirmation and embrace of life" (ibid., pp. 107-8, 168).

Along with courage and loyalty (to the resistance group), Tessman highlights anger as one of burdened virtues of the oppressed. By critically surveying feminist writings on anger, on the one hand, she endorses anger as a moral virtue of the oppressed in their resistance against systemic injustice. As Audre Lorde conceives anger as her "response to racism" and argues that "anger is loaded with information and energy" (Lorde 2007, pp. 124-27), Tessman acknowledges "positive epistemic value in anger" that provides the oppressed with information about "the systemic nature of their mistreatment" and subordination (Tessman 2005, p. 119). In other words, anger is a moral virtue that enables the oppressed to make moral judgments on the root cause of their suffering, systemic injustice and oppression: anger serves as a "cognitive interruption of the ideological rationalizations for [systemic] oppression and [unjust] privilege" (Jaycox 2016, p. 128). Anger also has moral motivational value that provides the oppressed with energy for a refusal to accept their subordinate positions in society and inspires "more spontaneous acts of defense against one's own or others' subordination"

5 Within the field of Christian ethics, I found that some works of scholars of color, especially those who stand on the tradition of liberation theology, could be seen as a kind of virtue discourse, but there are some reservation to claim themselves as a "virtue ethicist" given their strong opposition to the conventional virtue discourses, exemplified by the works of Stanley Hauerwas. For example, a Cuban American Christian ethicist Miguel A. De la Torre (2004) criticizes Hauerwas' virtue discourse and argues for the fundamental irreconcilability between liberative ethics and virtue ethics given the historical realities that the principles of virtue ethics have implemented to gloss over injustice. However, as the anonymous reviewer pointed out in the review process, some liberation theologians and ethicists have dealt with certain moral values and powers (character traits) of the oppressed embedded in their praxis against oppression and for social transformation (social flourishing). In other words, they implicitly or explicitly argue for liberating virtues of the oppressed. For example, although Gustavo Gutierrez (1983) does not explicitly use language of virtue in The Power of the Poor in History, he argues for the moral power of the oppressed, specifically epistemic value and power, in constructing liberating theology. Recently, Leonardo Boff explicitly used language of virtue and suggested four core virtues-"hospitality, co-living, tolerance, and communality" —of the global communities as the conditions for "the so-desired and liberating globalization" (Boff 2011, pp. 4-5). 
(Tessman 2005, p. 118-19). Anger as a morally praiseworthy trait motivates the oppressed to engage practices of resistance against systemic oppression.

On the other hand, Tessman also points out the tragic nature of anger. Being mistargeted and/or excessive in degree, it imposes costly burdens on its bearers, driving them apart from their own flourishing (Tessman 2005, p. 120). First, the oppressed have to risk anger hitting the wrong target (ibid., p. 121). Suffering from "the internalization of oppression", they are vulnerable to misdirecting their anger toward themselves (ibid., p. 120). This potential self-hatred is a costly burden that the oppressed have to bear while engaging resistance. Second, under conditions of great and prolonged structural injustice, the oppressed are highly likely to feel anger too much or too strongly. Following the Aristotelian system of virtues that calculates a virtuous mean relative to particular contexts, Tessman argues that the oppressed need to feel a tremendous level of morally praiseworthy anger as proportionate to the context of grave systemic injustice (ibid., p. 124). However, tragically, they are unlikely to "metabolize" their tremendous anger and "suffer from the level of anger prescribed for them, even if such a high level best serves their oppositional struggles" (ibid., p. 124). Although anger at structural injustice can serve as moral resources for the oppressed, it is tragically costly in leading the oppressed to take risk, danger, and personal loss/sacrifice: the virtue of anger can "become consuming" (ibid., p. 125).

Tessman's account of burdened virtues suggests the hardships of the oppressed under structural oppression and captures the tragic nature of the virtue of anger in their political struggles for liberation. Her account helps us to avoid romanticizing resistance against systemic injustice by suggesting that such virtue is costly and can consume the resisters' lives. Although she affirms that anger is a morally praiseworthy virtue within the conditions of oppression, she acknowledges her account of virtues of the oppressed as "pessimistic" (Tessman 2005, p. 10). She contends that her pessimism—-"revealing how destructive oppression is of the possibilities for flourishing" - emphasize the grave evil of oppression and calls for "the necessity of oppositional politics" (ibid., p. 10).

However, I argue that her account of burdened virtues is too pessimistic and effectively rules out the possibility that the virtue of anger can be constructive in contributing to the flourishing of the oppressed in their political resistance. What she misses in her project on virtue ethics for liberatory struggles is the importance and presence of community in the prolonged journey to flourishing. In his "Toward Thriving Communities", Brian Stiltner (2016) highlights the role and importance of communities in promoting the character and flourishing of persons in communities. Taking an example of the Le Chambon community in southern France whose residents exercised virtuous moral agency in transforming their village as a hiding place for Jews, he argues that "the presence of other people acting in a certain way can embolden people to live up their virtues," which have been learned in community (ibid., pp. 115-16). In community, people can find "the courage to endure the burdening of their virtues" (ibid., p. 116). He also argues that community can make flourishing more achievable by providing a variety of physical, psychological, and spiritual resources for their own flourishing (ibid., p. 117).

Developing Stilner's argument, I argue that a community of the oppressed not only encourages their members to endure the burdens of anger in resistance but also enables them "share" their burdens with one another (Shin 2016, p. 19). Through this communal sharing of the burden, the oppressed can transform burdened anger into thriving anger that is conducive to their own flourishing, specifically, the healthy affirmation and embrace of life, not the destructive consumption and sacrifice of life. In this third section of this essay, this argument is further examined and supported by the author's empirical research of South Korean minjung's political resistance against the Park Chung-hee regime in the 1970s. Specifically, the third section engages in a comparative analysis of a life-consuming suicide protest of a college student Kim Sang-jin and a life-affirming/flourishing protest of the mothers and wives of political victims, who were mostly Christians, against the Park regime's state repression and political violence. 


\section{The Communal Sharing of the Burdens of Anger and the Flourishing of the Oppressed}

In 1972, Park Chung-hee, who was elected as President of South Korea in 1963 following his military coup, promulgated the Yushin Constitution along with the National Security Law and the Anti-Communist Law. The Yushin Constitution severely limits the democratic process in South Korea by (1) "denying citizens the right to vote for the president" and (2) extending "the length of a single presidential term to six years" with the extended number of terms, and (3) "compromising the independence of the legislative and judicial branches of government" (Chang 2015, p. 24). A lot of citizens, especially young college students and workers, raised dissenting voices against the Park regime and marched on the street calling for the abolition of the Yushin-Dictatorship. The Park regime viciously oppressed them through the fabricated charges of being Communists, North Korea Sympathizers, or Reds and the unjust arrest, imprisonment, torture, and even execution (as kwon "legal murder"). This kind of political oppression and indeed state violence was justified and normalized in the name of upholding the laws and protecting national security. The normalized state violence was the mark of totalitarianism, which was consolidated by the promulgation of the Yushin Constitution as the oppressive structure.

The Park regime's totalitarian oppression culminated in two notorious events in 1974. College students formed the National Democratic Youth and Student Alliance (Mincheonghakryun) and planned a nationwide mass protest against the Park's regime (Chang 2015, pp. 70-71). By putting the charge of the violation of emergency decree 4 of the Yushin Constitution, approximately 250 college students were arrested and received "varying sentences ranging from a few years in jail to a death penalty" (Shin 2015, pp. 84-85). A month after the Mincheonghakryun incident, eight members of the People's Revolutionary Party (Inhyeokdang) were falsely charged with the violation of the National Security Law and accused of being "hardcore communists working under directives from North Korea" (ibid., p. 84). Tragically, after a year of imprisonment, they received the death penalty and were executed within twenty-four hours of sentencing by Supreme Court. This Inhyeokdang incident has been known as a case of legal murder by the Park regime.

The promulgation of the Yushin Constitution and the following Mincheonghakryun and Inhyeokdang incidents tremendously incited individual citizens' anger, and their anger motivated them to engage political resistance against the Park regime. Kim Sang-jin, student of Seoul National University, was one of these political resisters. His journals were filled with his furious anger at structural oppression and totalitarian violence:

How can they [Park Chung-hee and his followers] commit such brutal injustice [the legal murder of the Inhyeokdang members] with the mask of human beings? I cannot understand at all. It is a duty as a human to show at least minimum compassion to other fellow humans even though they committed wrong deserving the death penalty ... But, this incident is literally a murder! The murder! And heinous brutality inciting the great anger of people and also Heaven! (Kim 2003, p. 150)

Kim's furious anger led him to take leadership in organizing mass protest at Seoul National University. On 11 April, 1975, two days after the legal murder of the Inhyeokdang members, Kim stood in front of hundreds of student resisters and started to read aloud his conscience statement in anger:

Look at the dark wind of oppression and delusion! We now condemn the advent of the dreadful military state that suffocates our political liberty. This is the way for our people and history, and this is the way for striving for our beloved nation's democracy, and this is the way for achieving eternal social justice ... (Kim 2003, p. 173)

6 All translation of this source is mine other than noted separately. 
While reading this statement, he abruptly pulled out a knife, stabbed himself his abdomen, and cut it from the left to the right. His blood spilled out over the podium. He died before arriving at a hospital.

Kim's suicide was indeed his utmost protest against the Park regime and its brutal oppression. His ultimate sacrifice filled with great anger evoked public anger, galvanized the public into democratic movements, and marked a major turning point in South Korea's democratization in the 1970s. In Kim's case, anger might be considered as a morally praiseworthy virtue that equipped him with the cognitive power to perceive the systemic nature of the Park regime's oppression and the foundational energy for his protest against systemic injustice. In other words, Kim's suicide protest in his virtuous anger is distinguished from a typical suicidal act. Kim's case represents his virtue as his intentional sacrifice unto death contributed to enhancing flourishing, especially social flourishing—enlightening Korean citizens to recognize realities of injustice and empowering them to work for justice-in the context of political oppression.

However, this virtuous anger is tragically burdened: it disconnected him from his own flourishing, the affirmation of his life. As Tessman claims, Kim felt an excessive level of anger as proportionate to the context of grave systematic oppression, the legal murder of the innocent citizens. This excessively strong anger tragically damaged Kim's moral imagination to pursue an alternative life-affirming protest to the life-sacrificing protest: as "the only virtuous option" he totally sacrificed himself for democracy. ${ }^{7}$ As he wrote down Thomas Jefferson's call to sacrifice in his conscience statement-“"the tree of democracy lives on by consuming blood"- - the burdened anger consumed his blood on the altar of democracy (Kim 1988, p. 29) ${ }^{8}$. For him, the cost of bearing the burdens of anger was his own life.

One day before his tragic death, Kim revealed his deep sense of solitude and agony while having conversations with his fellow student resisters:

I devoted my youth to Hanel [a student organization at SNU for political thoughts and actions]. But there is no one in Hanel who can share my will. Is there anyone who can die together? If so, come to me ... (Kim 2003, p. 160)

I argue that Kim did not have a genuine community that can share the burdens of his anger. Although he belonged to his group of fellow student resisters (Hanel), he could not find anyone who could share the burdens of anger. He had to bear the costly burden alone unto his death in order to achieve the goal of democratization. In the absence of communal sharing of the burdens, his virtuous but burdened anger tragically consumed his life. ${ }^{9}$

However, from my field research in South Korea on South Korean women's democratic movements, I found the possibility of transforming burdened anger into thriving anger through the communal sharing of the burdens in resistance. From September 1974, the mothers of the arrested members of Mincheonghakryun, the wives of members of Inhyeokdang, and other families of political victims formed their own political organization, the Association of the Families of the Arrested (Kusokja-kajok-hyupeuihoe, henceforth Kukahyup) and engaged their political resistance against the Park regime. Most of them had been housewives (or apolitical agents), but they successfully cultivated their political agency. Like Kim's case, for the Kukahyup members, feeling and expressing anger were decisive in the formation and sustainment of their political agency for resistance.

It is important to note that most Kukahyup members were Christians, and they organized a prayer meeting, which they called the "Thursday prayer meeting", as faithful Korean Christians who have been formed to pray to overcome their ordeals throughout history. In this prayer service, the Kukahyup members expressed and exchanged their authentic emotions, including anger. For many

\footnotetext{
This damaged moral imagination can be found in other suicide protesters. See B. C. Ben Park's article (Park 2004).

All translation of this source is mine other than noted separately.

I do want to note that the absence of communal sharing of the burdens of anger is one of many other factors that contributed to Kim's suicide protest. However, for the purpose of this paper, I only focus on this factor here.
} 
of them, expressing their great anger at the Park regime was the first subversive political action. Their anger culminated in the prayer meeting right after the execution of the members of Inhyeokdang. The mothers cried with the wives of the executed, and they indignantly shouted together "Throw away the murderous regime" and "Park Chung-hee is the murderer" and exchanged their feelings of indignation and sorrow (Kim and Lee 2007, p. 75). ${ }^{10}$

While their political resistance was filled and motivated by great anger, the mothers and wives of Kukahyup did not employ any violent and self-harming tactics of protest (e.g., suicide protest), but nonviolent and life-affirming/flourishing resistance against the Park regime's oppression. While engaging their political resistance, it is hard to say that they never sacrificed themselves for taking care of their arrested families and for achieving democracy. In other words, they also had to bear the burdens of anger in resistance. Nevertheless, they wisely managed the extent of their sacrifice-attaining the virtuous mean-and affirmed their own lives through the communal sharing of the burdens of anger.

From my interviews with the former members of Kukahyup, I discovered that some of them described their practices of resistance as pumashi (or $\left.p^{\prime} u m a s s i\right)$ : a labor-reciprocating system originated from traditional agricultural society in South Korea (Kim 2016, pp. 69-70). For example, they always went together the trial of each political prisoner, and they referred this communal practice of accompaniment and resistance as jaepan [court trial] pumashi. In Korean society, traditionally pumashi as a labor exchange system in the agricultural society "contributes directly and indirectly to the initiation and maintenance of interpersonal relationship": pumashi performed among members of community serves as a "clear indication of the existence between them of a social network" (Kim 1981, pp. 42-43). By reappropriating this traditional interpersonal relationship mode in the context of political resistance, they formulated a burden-sharing community, which contributed to the affirmation of their own lives. In other words, through the practices of pumashi, they shared their burdens of anger with one another, and their shared burdens enabled them to achieve their own flourishing, the affirmation and embrace of life, not the destructive consumption and sacrifice of life.

More importantly, in this burden-sharing community, the Kukahyup members transformed burdened anger into thriving anger as a moral virtue for attaining specific good for their own flourishing: "the ability to imagine realistically alternative possible futures" (MacIntyre 2001, p. 83). Although Kim Sang-jin had hope for democratization of his country and the realization of eternal social justice, his burdened anger did not allow him to imagine an alternative path to this bright future other than offering his body as a living sacrifice on the altar of democracy and justice. On the other hand, the mothers and wives of Kukahyup engaged in burden-sharing practices for guarding against the damage on their imaginative capacity and consequently promoting human flourishing, including their own flourishing.

According to the Catholic social thought, the burden-sharing community can be understood as the community of solidarity. Solidarity is one of "social virtues," "traits that help the community flourish, develop in members through their participation in the community," in the Catholic tradition (Stiltner 2016, p. 116). In Pope Paul VI's Populorum Progression solidarity is designated as the foundational moral and social value of "the development of all humanity" (Pope 1967). Then, Pope John Paul II produced Sollicitudo Rei Socialis for the twentieth anniversary of Populorum Progression and declared solidarity as "a moral and social attitude, as a 'virtue'" (Pope 1987). Solidarity as a social virtue is not a mere "feeling of vague compassion or shallow distress at the misfortunes of so many people, both near and far" (ibid.). Rather, it is "a firm and preserving determination to commit oneself to the common good," that is, "the good of all and of each individual" (ibid.) According to a Catholic moral theologian Meghan J. Clark, a social virtue of solidarity is the mean between the two vices of deficiency and excess: "excessive individualism" and "any form of [totalitarian] collectivism in which persons are subsumed by the whole or subverted to it" respectively (Clark 2014, pp. 31-34).

10 All translation of this source is mine other than noted separately. 
In other words, solidarity as a social virtue should involve a "firm and preserving determination to both individual dignity and the integrity of communities" which sacrifices "neither the individual nor the common good" (ibid., p. 31). In practicing solidarity within a community, each member of the community secures one's own individual flourishing and at the same time contributes to enhancing the community's flourishing, the common good. ${ }^{11}$

A key example of the burden-sharing community (or the community of solidarity) is Kukahyup's victory shawl project. Given the prolonged struggles for democracy and justice, the Kukahyup members felt a tremendous level of anger, frustration, and sorrow. In order to heal their wounded and worn-out souls, they found a collective practice of healing: knitting what they called a victory shawl. After their public protest in the streets or jaepan pumashi, they gathered in the Christian building and knitted the shawls together. They sent the shawls to their sons, daughters, and husbands in prison. The shawls became "the symbol of resistance" for the political prisoners and served as a moral resource for sustaining their hope for restoration of democracy and human rights in near future (Ko 2016, p. 266). ${ }^{12}$

More importantly, for the Kukahyup members, knitting the victory shawls was their spiritual practice. They intentionally chose the shawl's color and shape in order to live out their theological belief in the resurrection of Christ. Its purple-color was adopted from the Christian liturgical tradition of using this color in the season of Lent that remembers the passion of Christ and prepares for the resurrection of Christ. Its V-shape (and even its name) symbolizes their belief in the final victory of Christ over evil, the Park regime's vicious oppression. Their hope shaped in the theological conviction is similar to Kim Sang-jin's hope expressed in a secular language, but the Kukahyup members wove the social fabric of the burden-sharing community and knitted the yarns of the alternative life-flourishing path reflecting the life-giving power of the resurrected Christ. According to my interview with a key leader of Kukahyup, while the Kukahyup members identified their imprisoned sons, daughters, and husbands as "small Christs" who bear their own cross on the path to democracy and justice, they identified themselves as "the women on the path" who passionately embrace their agony and suffering. ${ }^{13}$ By knitting the shawls together, they embraced their family members' suffering. I argue that the life-giving power of the resurrected Christ was abundantly present in this embracement of suffering as in the women in Scripture, who came to the tomb to remember and mourn for Christ, were empowered as the first witness of the resurrection. Christ's life-giving power following resurrection experienced in the burden-sharing community transformed the burdened anger of the Kukahyup members into "thriving anger" which energized them to pursue the life-flourishing path to the final victory over evil.

\section{Conclusions: Toward Thriving Anger in Resistance}

For the oppressed, some morally praiseworthy virtues are recommended or required to empower themselves to debunk the root cause of their suffering and engage political resistance against systemic injustice and oppression. Anger-having both moral epistemic and motivational values-is one of the moral virtues of the oppressed in resistance. However, as Tessman points out, the virtue of anger is costly burdened, and the historic case of Kim Sang-jin's suicide protest shows that anger can consume a resister's body and blood on the altar of justice and liberation. However, this essay argues for the possibility of transforming burdened anger into thriving anger that might contributes to the affirmation and embrace of the lives of resisters - the flourishing of the oppressed. The key to this moral transformation is the communal sharing of the burdens of anger in resistance. The South

11 Recently, Tisha M. Rajendra challenges the conventional Catholic accounts of solidarity from "the perspectives of first-world persons" who do not have "any obvious connects to suffering and marginalized peoples" (Rajendra 2019, pp. 97-98).

12 All translation of this source is mine other than noted separately.

13 Jong-sook Lee, interviewed by Wonchul Shin, Seoul, South Korea, 6 November 2017. Please note that I use a pseudonym for my interviewee. 
Korean mothers and wives of political victims successfully formed a burden-sharing community, a community of solidarity (Kukahyup), by creatively reappropriating the traditional agricultural mode of interpersonal relationship (pumashi), their domestic skills as housewives, and their Christian belief in the resurrection of Christ in the context of political resistance. Through their practices of burden-sharing (or solidarity), these women not only affirmed their own lives but also other individual citizens' lives. With the communal sharing of the burdens, anger can be a thriving moral virtue rather than a burdened virtue, which enables the oppressed to embrace a possibility of their own flourishing while engaging in resistance against systematic injustice and oppression.

Funding: This research received no external funding.

Conflicts of Interest: The author declares no conflict of interest.

\section{References}

Bennett, John C. 1993. Positive Uses of Anger. The Living Pulpit 2: 8-9.

Boff, Leonardo. 2011. Virtues: For Another Possible World. Eugene: Wipf and Stock Publishers.

Cannon, Katie Geneva. 1998. Katie's Canon: Womanism and the Soul of the Black Community. New York: Bloomsbury Academic.

Chang, Paul Y. 2015. Protest Dialectics: State Repression and South Korea's Democracy Movement, 1970-1979. Stanford: Stanford University Press.

Choi, Ki Joo. 2018. The Priority of the Affections over the Emotions: Gustafson, Aquinas, and an Edwardsean Critique. Journal of the Society of Christian Ethics 38: 113-29. [CrossRef]

Clark, Meghan J. 2014. Anatomy of a Social Virtue: Solidarity and Corresponding Vices. Political Theology 15: 26-39. [CrossRef]

Corrigan, Kevin. 2009. Evagrius and Gregory: Mind, Soul and Body in the 4th Century. London: Ashgate.

De la Torre, Miguel. 2004. Virtue Ethics: A Liberationist Response. In Christian Faith and Social Justice: Five Views. Edited by Vic McCracken. New York: Bloomsbury Publishing, pp. 158-61.

Deely, John. 1997. The Seven Deadly Sins and the Catholic Church. Semiotica 117: 67-102. [CrossRef]

Gutierrez, Gustavo. 1983. The Power of the Poor in History: Selected Writing. Translated by Robert R. Barr. Maryknoll: Orbis Books.

Harris, Melanie L. 2010. Gifts of Virtue, Alice Walker, and Womanist Ethics. New York: Palgrave Macmillan.

Harrison, Beverly Wildung. 1981. The Power of Anger in the Works of Love: Christian Ethics for Women and Other Strangers. Union Seminary Quarterly Review 36: 41-57.

Jaycox, Michael J. 2016. The Civic Virtues of Social Anger: A Critically Reconstructed Normative Ethic for Public Life. Journal of the Society of Christian Ethics 36: 123-43. [CrossRef]

Kim, Joohee. 1981. P'UMASSI: Patterns of Interpersonal Relationships in a Korean Village. Ph.D. dissertation, Northwestern University, Evanston, IL, USA.

Kim, Jong-chan, ed. 1988. Bul-ui Gilog Pi-ul Gilog Jeg-eum-ui Gilog [The Records of Fire, Records of Blood, and Records of Death]. Seoul: Silchoenmunhak.

Kim, Nam-il. 2003. Sidaeui Bulkot Kim Sang-jin [Flame of Era Kim Sang-jin]. Seoul: Korea Democracy Foundation.

Kim, Ki-Hong. 2016. A Study on the Prototype, Transformation and Re-structuration of Human Relationships in the Modern and Contemporary Eras of S. Korea. Journal of Korean Studies 57: 69-70.

Kim, Seolee, and Kyungeun Lee. 2007. Jatbit Sidae Boratbit Goeun Ggoom: 7,80 Nyondae Minjuhwa-Woondong-Euiroseoeui Kajok-Woondong IIn the Grey Era Violet-Colored Beautiful Dream: Family Movement as Democracy Movement in the 70-80s]. Seoul: Korea Democracy Foundation.

Ko, Myungsup. 2016. Lee Hee-ho Pyungjeon: Gonanui Gil, Sinnyeomui Gil [Biography of Lee Hee-ho: The Way of Passion, the Way of Conviction]. Seoul: Hankyoreh.

Lester, Andrew D. 1983. Coping with Your Anger: A Christian Guide. Philadelphia: The Westeminster Press.

Lorde, Audre. 2007. Sister Outsider: Essays and Speeches by Audre Lorde. Berkeley: Crossing Press.

MacDonald, Sarah E., and Nicole Symmonds. 2018. Rioting as Flourishing? Reconsidering Virtue Ethics in Times of Civil Unrest. Journal of the Society of Christian Ethics 38: 25-42. [CrossRef]

MacIntyre, Alasdair. 2001. Dependent Rational Animals: Why Human Beings Need the Virtues. Chicago: Open Court Publishing. 
Mattison, William. 2004. Virtuous Anger? From Questions of Vindicatio to the Habituation of Emotion. Journal of the Society of Christian Ethics 24: 159-79. [CrossRef]

Park, B. C. Ben. 2004. Sociopolitical Contexts of Self-Immolations in Vietnam and South Korea. Archives of Suicide Research 8: 81-97. [CrossRef] [PubMed]

Pope, Pual IV. 1967. Populorum Progressio: Encyclical of Pople Paul VI on the Development of Peoples. Available online: http://w2.vatican.va/content/paul-vi/en/encyclicals/documents/hf_p-vi_enc_26031967_populorum. html (accessed on 8 May 2020).

Pope, John Paul II. 1987. Sollicitudo Rei Socialis. Available online: http://www.vatican.va/content/john-paul-ii/en/ encyclicals/documents/hf_jp-ii_enc_30121987_sollicitudo-rei-socialis.html (accessed on 8 May 2020).

Powell, Samuel M. 2016. The Impassioned Life: Reason and Emotions in the Christian Tradition. Minneapolis: Fortress Press.

Rajendra, Tisha M. 2019. Burdened Solidarity: The Virtue of Solidarity in Diaspora. Journal of the Society of Christian Ethics 39: 93-109. [CrossRef]

Ruether, Rosemary Radford. 1973. Sexism and the Theology of Liberation: Nature, Fall, and Salvation as Seen from the Experience of Women. The Christian Century 90: 1224-29.

Ruether, Rosemary Radford. 1993. Anger and Liberation Grace. The Living Pulpit 2: 6-7.

Russell, Keith A. 1993. Prophetic Anger from the Perspective of Jeremiah. The Living Pulpit 2: 13.

Shin, Youngtae. 2015. Protest Politics and the Democratization of South Korea: Strategies and Roles of Women. Lanham: Rowman \& Littlefield Publishers.

Shin, Won Chul. 2016. The Virtues of Resilience: Virtue Ethics for Strangers in America. Journal of Asian American Theological Forum 3: 14-19.

Stiltner, Brian. 2016. Toward Thriving Communities: Virtue Ethics as Social Ethics. Winona: Anselm Academic.

Tessman, Lisa. 2005. Burdened Virtues: Virtue Ethics for Liberatory Struggles. New York: Oxford University Press.

Troeger, Thomas H. 1993. Holy Anger. The Living Pulpit 2: 48.

Werpehowski, William. 1996. Do You Do Well to Be Angry? The Annual of the Society of Christian Ethics 16: 59-77. [CrossRef]

Yeager, Diane M. 1997. Anger, Justice, and Detachment. The Annual of the Society of Christian Ethics 17: 167-88. [CrossRef]

(C) 2020 by the author. Licensee MDPI, Basel, Switzerland. This article is an open access article distributed under the terms and conditions of the Creative Commons Attribution (CC BY) license (http://creativecommons.org/licenses/by/4.0/). 